\title{
TANTANGAN ALKI UNTUK MEWUJUDKAN CITA-CITA INDONESIA POROS MARITIM DALAM PERSPEKTIF HUKUM
}

\author{
Yuniarti Dwi Pratiwi ${ }^{1}$
}

\begin{abstract}
Abstrak: Dalam catatan sejarah terekam bukti-bukti bahwa nenek moyang bangsa Indonesia menguasai lautan Nusantara, bahkan mampu mengarungi samudra luas hingga ke pesisir Madagaskar di Afrika bagian selatan. Hal tersebut membuktikan bahwa nenek moyang bangsa Indonesia telah memiliki jiwa bahari dalam membangun hubungan dengan bangsa lain. Berangkat atas dasar inilah, pemerintahan lima tahun Presiden Joko Widodo-Jusuf Kalla mengusung visi yang menjadikan Indonesia sebagai "poros maritim" sebagai dasar investasi guna mengembalikan kejayaan masa lampau Indonesia di dunia maritim. Mewujudkan cita-cita sebagai negara maritim bukan berarti tanpa hambatan. Hal ini mengingat sejak meratifikasi United Nations Convention on the Law of the Sea (UNCLOS) 1982 dan sejak berlakunya Alur Laut Kepulauan Indonesia (ALKI), mau tidak mau menjadikan perairan Indonesia "terbuka" bagi kapal-kapal asing atau negara asing untuk melaksanakan hak lintas mereka di perairan Indonesia. Posisi ini juga memberikan permasalahan kompleks baik masalah yang berkaitan dengan ekonomi, hukum, keamanan, dan pertahanan negara. Begitu banyaknya pekerjaan rumah untuk mewujudkan visi Indonesia sebagai poros maritim, oleh karena itu dibutuhkannya instrumen hukum yang bersinergi.
\end{abstract}

Kata Kunci: UNCLOS 1982, ALKI, Poros Maritim, Hak Lintas, Perairan Indonesia

\section{PENDAHULUAN}

Negara Indonesia memiliki wilayah perairan yang lebih luas daripada daratan. Oleh karena itu, peran wilayah laut menjadi sangat penting bagi kehidupan bangsa dan negara. Bila kita kembali melihat kepada sejarah, kerajaan Sriwijaya (Nusantara I) dan Kerajaan Majapahit (Nusantara II) merupakan contoh kejayaan maritim di Nusantara. Kejayaan Indonesia sebagai negara maritim dimasa lalu muncul karena paradigma masyarakatnya yang mampu menciptakan visi maritim sebagai bagian utama dari kemajuan budaya, ekonomi, politik, sosial dan pertahanan. Mereka mempunyai ketajaman visi maritim yang tinggi terhadap keunggulan strategis letak geografis wilayah bahari Indonesia. Kemampuan tersebut dilakukan dengan segenap politicalwill pemimpin dan rakyatnya.

Bercermin pada masa lalu, Indonesia pernah mencetak tinta emas dengan kejayaan kerajaan Sriwijaya, Majapahit, hingga Demak, oleh sebab itu Presiden ketujuh Republik Indonesia Joko Widodo dipenghujung pidato kepresidenannya di Gedung DPR/MPR pada hari Senin, 20 Oktober 2014 menyampaikan cita-citanya mewujudkan Indonesia menjadi poros maritim dunia ${ }^{1}$

Terkait dengan gagasan poros maritim yang mengedepankan peran laut Indonesia, tak bisa dilepaskan dari hubungan Indonesia dengan dunia internasional. Ini merupakan konsekuensi yuridis karena Indonesia telah meratifikasi United Nations Convention on the Law of the Sea(UNCLOS) 1982 sebagai hukum positif internasional, yang kemudian melahirkan Alur Laut Kepulauan Indonesia(ALKI). ALKI menjadi representasi dari luasnya wilayah perairan yurisdiksi nasional yang berkaitan erat dengan status Indonesia sebagai sebuah negara maritim.

ALKI sendiri merupakan wilayah terbuka yang membagi Indonesia dalam empat kompartemen strategis. Dari segi geografis, terletak pada posisi silang antara dua samudra yang merupakan jalur penting perdagangan dunia, yaitu Samudra Hindia dan Samudra Pasifik. Konsekuensi logis dari sisi geografis

\footnotetext{
${ }^{1}$ Penulis: Yuniarti Dwi Pratiwi, S.H., Pemerhat i pertahanan, dapat dihubungi di yuniartiibbas@gmail.com

${ }^{1}$ ParadigmaGeomaritimStrategiMewujudkan Indonesia SebagaiPorosMaritimDuniadalamPerspektifGeografi, BadanInformasiGeospasial, Hal. 18
} 
ini adalah perairan Indonesia memiliki nilai politik dan strategi keamanan yang sangat penting bagi negara lain. Dari segi keamanan adanya masalah klasik seperti ancaman keamanan laut belum dapat terselesaikan hingga kini. Belum lagi tantangan dari banyaknya pelanggar hukum yang pada akhirnya merugikan Indonesia.

Kenyataan yang dihadapi inilah kemudian menimbulkan sebuah tantangan bagi bangsa ini dalam menciptakan visi menjadi poros maritim dunia. ALKI menjadi salah satu bagian yang berpengaruh dalam memperjuangkan cita-cita ini. Salah satu tantangan ini adalah sinergi instrumen hukum positif Indonesia terkait dengan perairan di wilayah Indonesia.

\section{ISI PENELITIAN}

\subsection{Sejarah Perkembangan Wilayah Kedaulatan NKRI}

Perlu kita melihat ke belakang sebentar tentang perkembangan wilayah laut Indonesia, bahwa negara Indonesia merdeka tanggal 18 Agustus 1945, sedangkan kalau kita memerhatikan tentang peraturan yang mengatur mengenai wilayah laut jauh sebelum negara Indonesia merdeka. Peraturan itu berkaitan dengan hak kepemilikan wilayah laut yakni peraturan yang dikeluarkan tentang klaim wilayah laut tentang jaraknya yang diukur dari wilayah darat dari suatu negara.

Peraturan wilayah laut Indonesia pertama kali ditentukan dengan TerritorialeZeeenMarietiemeKringenOrdonanti $e$ (TZMKO) peraturan tentang laut teritorial yang dibuat pada zaman kolonial Belanda tahun 1939. Peraturan ini mengatur bahwa klaim terhadap wilayah laut teritorial negara Indonesia yakni 3 mil. Berdasarkan konsepsi TZMKO tahun 1939, lebar laut wilayah perairan Indonesia hanya meliputi jalur-jalur laut yang mengelilingi setiap pulau atau bagian pulau Indonesia. Artinya, antar pulau di Indonesia terdapat laut internasional/laut bebas/laut lepas yang memisahkan satu pulau dengan pulau lainnya. Misalnya antara Pulau Jawa dengan Pulau Kalimantan dipisahkan dengan adanya laut bebas dan lain-lain. ${ }^{2}$

Dengan adanya laut bebas antar pulau-pulau di Indonesia tentunya mengancam persatuan dan kesatuan bangsa. Maka pasca kemerdekaan Indonesia, pada tanggal 13

${ }^{2}$ MemahamiHukumLaut Indonesia, NurYanto, Jakarta, Mitra Wacana Media, Hal. 13
Desember 1957 pemerintah Indonesia mengumumkan Deklarasi Djuanda. Dalam Deklarasi Djuanda disebutkan bahwa:

"Bentuk geografi Indonesia sebagai satu negara Kepulauan yang terdiri dari beribu-ribu pulau mempunyai sifat corak tersendiri. Bagi keutuhan teritorial dan untuk melindungi kekayaan negara Indonesia semua kepulauan serta laut terletak diantaranya harus dianggap sebagai kesatuan bulat. Penentuan batas laut territorial seperti termaktub dalam TerritorialeZeenen Maritime KringenOrdonnantie 1939 Pasal 1 ayat (1) tidak sesuai lagi dengan pertimbanganpertimbangan di atas karena membagi wilayah daratan Indonesia dalam bagian-bagian terpisah dengan territorialnya sendiri-sendiri. Berdasarkan pertimbangan-pertimbangan itu, maka Pemerintah menyatakan bahwa segala perairan di sekitar, di antara, dan yang menghubungkan pulau-pulau yang termasuk negara Indonesia dengan tidak memandang daratan negara Indonesia dan dengan demikian bagian daripada wilayah pedalaman atau nasional yang berada di bawah kedaulatan mutlak Indonesia. Lalu-lintas yang damai diperairan pedalaman ini bagi kapalkapal asing dijamin selamat dan sekedar tidak bertentangan dengan/menganggu kedaulatan dan keselamatan negara Indonesia. Penentuan batas laut territorial yang lebarnya 12 mil diukur dari garis-garis yang menghubungkan titik-titik ujung terluar pada pulau-pulau negara Indonesia."3

Selanjutnya dalam perkembangannya dan dalam hubungan dengan masyarakat internasional, guna memperhatikan kepentingan masyarakat internasional yaitu tetap ada untuk lalu lintas laut damai bagi kendaraan asing di dalam perairan pedalaman Indonesia terbuka sekaligus menegaskan bahwa Pasal 1 ayat (1) angka 1 sampai dengan

4pada TerritorialeZeeenMarietiemeKringenOrd onantie(TZMKO)(Staatsblad 1939 No.442) tidak berlaku lagi.Pemerintah Indonesia mengeluarkan Undang-Undang Nomor 4 Prp 1960 tentang Perairan Indonesia tanggal 18 Februari 1960.

Dalam hal berlakunya secara internasional tentang hak klaim terhadap wilayah laut territorial baru puncaknya pada tahun 1982

${ }^{3}$ Konsep Negara

KepulauanPerspektifHukumLautdanPenetapanGaris Batas

Negara, IndienWinarwati, Setara Pres, Hal. 17 
telah disepakati bahwa lebar laut teritorial suatu negara 12 mil dengan adanya Konvensi Hukum Laut/UNCLOS 1982.Dalam konvensi hukum laut ini negara Indonesia telah melakukan ratifikasi melalui Undang-Undang Nomor 17 Tahun 1985 tentang Pengesahan UNCLOS 1982.

Dengan adanya klaim terhadap wilayah laut sampai 12 mil laut territorial tersebut memberikan perluasan terhadap wilayah suatu negara khususnya negara Indonesia, dan negara-negara lain pada umumnya. ${ }^{4}$

\subsection{Kedaulatan Negara Indonesia Pasca Meratifikasi UNCLOS 1982}

Kedaulatan atau sovereignty memiliki arti kekuasaan tertinggi dalam suatu negara yang di dalam negara tersebut tidak dihinggapi adanya kekuasaan lain. Pada awalnya, kebulatan dan keutuhan kedaulatan tidak dapat dibagi-bagi dan dipecah-pecah serta tidak dapat ditempatkan di bawah kekuasaan lain. Akan tetapi arti dan makna dari kedaulatan kini telah mengalami perubahan. Kedaulatan tidak lagi dipandang sebagai suatu yang bulat dan utuh, melainkan dalam batasbatas tertentu sudah tunduk pada pembatasan-pembatasan. Pembatasanpembatasan ini tidak lain adalah hukum internasional. Suatu negara yang berdaulat harus tetap tunduk pada hukum internasional serta tidak boleh melanggar atau merugikan negara lainnya. ${ }^{5}$

Dalam konteks kedaulatan di Indonesia, sebagai konsekuensi diratifikasinya Konvensi Hukum Laut 1982 (UNCLOS 1982) Indonesia berkewajiban untuk menyediakan Alur Laut Kepulauan. Kewajiban ini telah diatur dalam Pasal 47-53 Konvensi Hukum Laut 1982 Pasal 47 yang menyatakan bahwa negara kepulauan dapat menarik garis pangkal lurus kepulauan (archipelagicbaselines). Aturan ini kemudian ditransformasikan kedalam Undang-Undang Republik Indonesia Nomor 6 Tahun 1996 tentang Perairan Indonesia dan Peraturan Pemerintah Nomor 37 Tahun 2002 tentang Hak dan Kewajiban Kapal dan Peswat Udara Asing dalam Melaksanakan Hak Lintas Laut Kepulauan Melalui Alur Laut Kepulauan.
Apabila kapal asing yang sedang melakukan pelayaran internasional dalam melaksanakan hak lintas melalui ALKI baik kapal niaga maupun kapal perang dapat melintas tanpa harus meminta izin terlebih dulu kepada pemerintah Indonesia. Termasuk kapal selam asing juga dapat melintas tanpa harus muncul dipermukaan laut, namun hanya dikhususkan pada tiga alur laut yang telah disepakati. Jika melewati alur yang telah ditentukan maka dianggap telah melakukan pelanggaran. Berikut gambaran peta tiga Alur Laut Kepulauan Indonesia yang telah disetujui dan disahkan oleh pemerintah Indonesia pada tahun $2002 .^{6}$

Secara umum Indonesia memiliki tiga Alur Laut Kepulauan yaitu:

1. Alur Laut Kepulauan yang dapat dipergunakan untuk melaksanakan Hak Lintas Alur Laut Kepulauan, untuk pelayaran dari Laut Cina Selatan ke Samudra Hindia atau sebaliknua, melintasi Laut Natuna, Selat Karimata, Laut Jawa, dan Selat Sunda, adalah Alur Laut Kepulauan I yang garis sumbunya merupakan garis yang menghubungkan titiktitik penghubung 1-1 sampai dengan 1-5 sebagaimana tercantum dalam Daftar Koordinat yang dimaksud dalam Pasal 12 ayat (2);

2. Alur Laut Kepulauan yang dpat dipergunakan untuk melaksanakan Hak Lintas Alur Laut Kepulauan untuk pelayaran dari Laut Sulawesi ke Samudra Hindia, atau sebaliknya, melintasi Selat Makasar, Laut Flores, dan Selat Lombok, adalah Alur Laut Kepulauan II yang garis sumbunya merupakan garis yang menghubungkan titik-titik penghubung II-1 sampai dengan II-8 sebagaimana tercantum dalam daftar koordinat yang dimaksud dalam Pasal 12 ayat (2);

3. Alur Laut Kepulauan yang dapat dipergunakan untuk melaksanakan Hak Lintas Alur Laut Kepulauan untuk pelayaran dari Samudra Pasifik ke Samudra Hindia atau sebaliknya, melintasi Laut Maluku, Laut Seram, Laut Banda, Selat Omai, dan Laut Sawu, adalah Alur Laut Kepulauan IIIA yang garis sumbunya merupakan garis yang menghubungkan titik-titik penghubung IIIA-1 sampai dengan IIIA-13, sebagaimana 
tercantum dalam daftar koordinat yang dimaksud Pasal 12 ayat (2). ${ }^{7}$

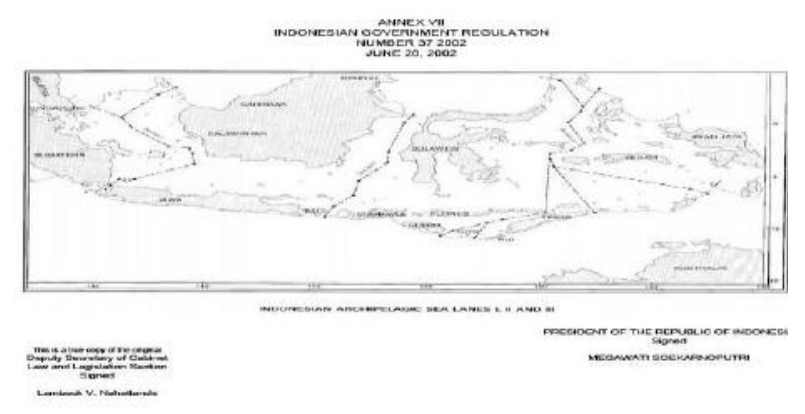

Gambar 1. Peta ALKI

Dengan dibukanya ALKI I, II, dan III tentu membuka pula peluang kehadiran berbagai konsekuensi keamanan di perairan Indonesia. Hal ini dikarenakan ketiga jalur ALKI tersebut jalur strategis dan sangat berarti bagi negara lain. Jalur itu digunakan oleh banyak negara untuk menopang kegiatan ekonomi mereka.

\subsection{Kondisi Keamanan ALKI dalam Perspektif Hukum}

Keberadaan ALKI sebagai representatif telah diratifikasinya Konvensi Hukum Laut 1982 (UNCLOS 1982) memberikan dampak penting baik secara positif maupun negatif bagi Indonesia dalam pergaulan intemasional. Salah satu dampak positif yang dapat dipetik adalah adanya potensi ekonomi yang sangat besar dari proses lalu lintas perdagangan intemasional yang melalui ketiga ALKI. Sedangkan salah satu dampak negatif yang sering terjadi adalah hilangnya sumber daya kelautan sebagai akibat rendahnya kemampuan memberikan perlindungan dan penjagaan dari pihak-pihak asing. Di samping itu beberapa isu yang terjadi diantaranya meliputi isu terorisme, lalu lintas obat terlarang, perompakan dan pembajakan bersenjata di laut, penyelundupan senjata, penyelundupan orang, perdagangan wanita dan anak-anak, kejahatan illegalfishingyang sering dilakukan oleh ribuan kapal asing.

Khusus masalah terakhir ini, Badan Pemeriksa Keuangan menunjukkan data potensi pendapatan sektor perikanan laut Indonesia jika tanpa illegalfishingmencapai Rp. 365 triliun per tahun. Namun akibat illegalfishing, menurut perhitungan Kementerian Kelautan dan Perikanan pendapatan tersebut hanya

${ }^{7}$ Pasal 11 PeraturanPemerintahNomor 37 Tahun 2002 tentangHakdanKewajibanKapaldanPeswatUdaraAsingdalamMel aksanakanHak Lintas LautKepulauanMelaluiAlurLautKepulauan berkisar Rp 65 triliun per tahun (Bakosurtanal, 2015). Sehingga setiap tahun Indonesia mengalami kerugian hingga ratusan triliun rupiah. $^{8}$

Dalam upaya penegakan hukum dan keamanan di laut, jika ditinjau dari Peraturan Perundang-undangan, kebijakan kemaritiman tidak diatur secara khusus dalam undangundang, tetapi termaktub dalam berbagai peraturan perundang-undangan, antara lain:

1. Undang-Undang Nomor 1 Tahun 1973 tentang Landasan Kontingen Indonesia, (Lembaran Negara Republik Indonesia Tahun 1973 Nomor 1, Tambahan Lembaga Negara Nomor 2994);

2. Undang-Undang Nomor 5 Tahun 1983 tentang Zona Ekonomi Eksklusif Indonesia, (Lembaran Negara Republik Indonesia Tahun 1983 Nomor 44, Tambahan Lembaga Negara Nomor 3260);

3. Undang-Undang Nomor 17 Tahun 1985 Pengesahan United Nations Convention on the Law of the Sea 1982, (Lembaran Negara Republik Indonesia Tahun 1985 Nomor 76, Tambahan Lembaran Negara Republik Indonesia Nomor 3319)

4. Undang-Undang Nomor 5 Tahun 1990 tentang Konservasi Sumber Daya Alam Hayati dan Ekosistemnya (Lembaran Negara Republik Indonesia Tahun 1990 Nomor 49, Tambahan Lembaga Negara Nomor 3419);

5. Undang-Undang Nomor 6 Tahun 2011 tentang Keimigrasian (Lembaran Negara Republik Indonesia Tahun 2011 Nomor 52, Tambahan Lembaga Negara Nomor 5216);

6. Undang-Undang Nomor 6 Tahun 1996 tentang Perairan Indonesia (Lembaran Negara Republik Indonesia Tahun 1996 Nomor 73, Tambahan Lembaga Negara Nomor 3647);

7. Undang-Undang Nomor 17 Tahun 2006 tentang Perubahan Atas Undang- Undang Nomor 10 Tahun 1995 tentang Kepabeanan (Lembaran Negara Republik Indonesia Tahun 2006 Nomor 93, Tambahan Lembaga Negara Nomor 4661);

8. Undang-Undang Nomor 32 Tahun 2009 tentang Perlindungan dan Pengelolaan Lingkungan Hidup, (Lembaran Negara Republik Indonesia Tahun 2009 Nomor 140, Tambahan Lembaga Negara Nomor 5059);

9. Undang-Undang Nomor 45 Tahun 2009 tentang Perubahan Atas Undang- Undang Nomor 31 Tahun 2004 tentang Perikanan,

${ }^{8}$ Tantangan ALKI dalamMewujudkanCita-Cita Indonesia SebagaiPorosMaritim, IsmahRustam, UniversitasMataram, Indonesian Perspective, Vol 1 No. 1 (Januari-Juni): 1-21, Hal 17 
(Lembaran Negara Republik Indonesia Tahun 2009 Nomor 154, Tambahan Lembaran Negara Republik Indonesia Nomor 5073);

10. Undang-Undang Nomor 34 Tahun 2004 tentang Tentara Nasional Indonesia (Lembaran Negara Republik Indonesia Tahun 2004 Nomor 127, Tambahan Lembaran Negara Republik Indonesia Nomor 4439);

11. Undang-Undang Nomor 1 Tahun 2014 tentang Perubahan Atas Undang- Undang Nomor 27 Tahun 2007 tentang Pengelolaan Wilayah Pesisir dan Pulau- Pulau Kecil, (Lembaran Negara Republik Indonesia Tahun 2014 Nomor 2, Tambahan Lembaran Negara Republik Indonesia Nomor 5490);

12. Undang-Undang Nomor17 Tahun 2008 tentang Pelayaran, (Lembaran Negara Republik Indonesia Tahun 2008 Nomor 64, Tambahan Lembaran Negara Republik Indonesia Nomor 4849); ${ }^{9}$

Demikian pula institusi atau instansi pemerintah baik militer (TNI) maupun sipil nonmiliter yang memiliki kaitan dengan peran, tugas, dan fungsi dalam penyelenggaraan keamanan laut di wilayah perairan dan yurisdiksi Indonesia. Saat ini Indonesia mempunyai 13 (tiga belas) lembaga penegak hukum di laut yang mempunyai fungsi yang sama seperti Polisi Air(POLAIR), Kesatuan Penjagaan Laut dan Pantai Republik Indonesia (KPLP), dan Kementerian Kelautan dan Perikanan(KKP). Dalam undang-undang yang mengatur penegakan hukum di laut, dalam satu undang-undang subyek pelakunya bisa lebih dari satu instansi. Keadaan ini bisa memunculkan perbedaan persepsi kewenangan yang cenderung mengarah pada ego instansional. ${ }^{10}$

Perbedaan tersebut sangat memungkinkan terjadinya miskoordinasi yang berujung pada tidak efisien dan efektifnya penyelesaian permasalahan penegakan hukum dan keamanan di laut. Semua ini disebabkan karena tidak dalam satu sistem yang terintegrasi, serta dalam kesatuan komando dan kendali. Sehingga dapat dimengerti jika dalam pelaksananya sering terjadi overlappingkewenangan diantara instansi atau lembaga tersebut besar kemungkinan terjadi.

\footnotetext{
${ }^{9}$ PenegakanHukum di LautdenganSistem Single Agency Multitasks, EkaMartianaWulansari, RechtsVinding Online ${ }^{10}$ SinergitasParadigma Lintas

SektorDibidangKeamanandanKeselamatanLaut, Tri

SulistyaningtyasSusanto, Gramedia, Hal.182
}

Berbagai persoalan di atas membuat kita berpikir dan mencari solusi menyelesaikan persoalan dalam pelaksanaan penegakan hukum, keamanan, dan keselamatan di laut Indonesia. Berdasarkan berbagai pertimbangan dan kebutuhan mendesak bangsa ini untuk memiliki coastguard guna mewujudkan visi poros maritim, maka sejak disahkannya Undang-Undang Nomor 32 Tahun 2014 tentang kelautan dibentuklah Badan Keamanan Laut Republik Indonesia (BAKAMLA). BAKAMLA dibentuk sebagai Single Agency Multi Function, diharapkan pengendalian laut dapat dilakukan secara efektif dan efisien baik secara militer maupun non-militer, apalagi perairan Indonesia "terbuka" untuk negara-negara lain, yang dapat menimbulkan potensi ancaman dikarenakan terdapat Hal Lintas Damai sebagaimana tertuang dalam UNCLOS 1982. Akan tetapi, meskipun demikian pada kenyataannya masih banyak penegak hukum di wilayah laut Indonesia tumpang tindih. Oleh karena itu perlu diperjelas peranan BAKAMLA sebagai coastguard, guna tercapainya visi negara Indonesia sebagai poros maritim dunia.

\section{PENUTUP}

Bangsa Indonesia harusnya bersyukur karena berada di posisi strategis sebagai poros maritim dunia dan anugerah itu seharusnya dimanfaatkan dengan sebaik-baiknya untuk meningkatkan kesejahteraan bangsa. Menjadikan Indonesia sebagai poros maritim dunia bukanlah hal yang mudah, mengingat dengan adanya ALKI sejak meratifikasi Konvensi Hukum Laut 1982 yang menyebabkan Indonesia menjadi negara terbuka. ALKI ini tidak selalu menimbulkan masalah dan kerugian negara, sebagai bangsa yang cermat kita harus pandai memanfaatkan keadaannya untuk meraup keuntungan.

Namun gagasan poros maritim hendaknya juga didukung dengan mengerahkan insrtumen hukum yang terintegrasi. Keberadaan BAKAMLA sebagai Single Agency Multi Function diharapkan dapat mengintegrasi segala kewenangan, kekuatan dan kemampuan yang tercermin dalam struktur organisasi, mekanisme, prosedur dan ketentuan-ketentuan lain, guna mendukung kelancaran tugas penegakan hukum, keamanan dan keselamatan di laut, karena koordinasi dilakukan pada satu tangan (satu komando). 


\section{DAFTAR PUSTAKA}

Paradigma Geomaritim Strategi Mewujudkan Indonesia Sebagai Poros Maritim Dunia dalam Perspektif Geografi, Badan Informasi Geospasial

Rustam, Imah, Tantangan ALKI dalam Mewujudkan Cita-Cita Indonesia Sebagai Poros Maritim, Universitas Mataram, IndonesianPerspective, Vol 1 No. 1 (Januari-Juni): 1-21, Hal 18

Yanto, Nur, (2014) Memahami Hukum Laut Indonesia, Nur Yanto, Mitra Wacana Media, Jakarta

Winarwati, Indien, (2015), Konsep Negara Kepulauan Perspektif Hukum Laut dan Penetapan Batas Negara, Setara Pres, Jakarta

Sulityaningtyas, Tri (2015), Sinergitas Paradigma Lintas Sektor di Bidang Keamanan dan Keselamatan Laut, Gramedia, Jakarta

Bakosurtanal (2015) Mewujudkan Indonesia Sebagai Poros Maritim Dunia yang Maju dan Mandiri [Online], Badan Informasi Geospasial. Tersedia dalam: $<$ http://www.bakosurtanal.go.id/berita-s urta/show/mewujudkanindonesiasebagai-poros-maritim-dunia-yang-maj u-dan-mandiri [Diakses 10 Agustus 2016)

MartianaWulansari, RechtsVinding Online, Penegakan Hukum di Laut dengan Sistem Single Agency Multi Tasks,

United Nations Convention on the Law of the Sea 1982

Undang-Undang Nomor 17 Tahun 1985 tentang Pengesahan UNCLOS 1982

Undang-Undang Republik Indonesia Nomor 6 Tahun 1996 tentang Perairan Indonesia

Peraturan Pemerintah Nomor 37 Tahun 2002 tentang Hak dan Kewajiban Kapal dan Pesawat Udara Asing dalam Melaksanakan Hak Lintas Laut Kepulauan Melalui Alur Laut Kepulauan yang ditetapkan 